\title{
Factors Associated with Coping Mechanisms among Cancer Patients Undergoing Chemotherapy
}

\author{
Rio Akbar $^{1 *}$, Hajjul Kamil ${ }^{2}$ \\ ${ }^{1}$ Master Program of Nursing Science, Universitas Syiah Kuala, Banda Aceh, Indonesia \\ ${ }^{2}$ Department of Management Nursing, Universitas Syiah Kuala, Banda Aceh, Indonesia
}

\begin{tabular}{|c|c|}
\hline $\begin{array}{c}\text { Article History } \\
\text { Received: } 23.01 .2020 \\
\text { Accepted: } 19.02 .2020 \\
\text { Published: } 10.10 .2020\end{array}$ & $\begin{array}{l}\text { Abstract: The present study aims to investigate factors associated with coping } \\
\text { mechanism among cancer patients undergoing chemotherapy. The factors studied } \\
\text { include the age of patients, education level, marital status, occupation, stage of } \\
\text { cancer, presence of caregiver, acceptance of the illness and social support. Logistic } \\
\text { regression analysis was performed to examine the association between variables } \\
\text { and coping mechanisms. It was found that caregiver ( } \mathrm{p}=0,001) \text {, acceptance ( } \mathrm{p}= \\
0,001 \text { ) and social support ( } \mathrm{p}=0,001) \text { were independently associated with coping } \\
\text { mechanisms. It is recommended that the nurses in the chemotherapy ward to } \\
\text { provide supports to the patients in the form of information and education to help } \\
\text { maintaining the patient's coping mechanisms and to improve acceptance of their } \\
\text { illness. } \\
\text { Keywords: Coping Factor, Coping Mechanism, Cancer. }\end{array}$ \\
\hline \multicolumn{2}{|c|}{$\begin{array}{l}\text { Copyright (C) } 2020 \text { The Author(s): This is an open-access article distributed under the terms of the Creative Commons Attribution license which } \\
\text { germits unrestricted use, distribution, and reproduction in any medium for non commercial use (NonCommercial, or CC-BY-NC) provided the original } \\
\text { uthor and source are credited. }\end{array}$} \\
\hline
\end{tabular}

\section{INTRODUCTION}

The global burden of cancer increases significantly. It is estimated that more than 496,000 people died from the process of developing cancer each year. In 2012 there were approximately 14 million new cases of and 8.2 million deaths from cancer in the world [1]. Investigating the comorbidities of cancer is, therefore, significant. Furthermore, the interest in the psychosocial impact of severe physical illness has been growing the recent decade. The way patients cope with depression, anxiety and stress has become subject of the study. Coping mechanism and it associated factors have been intensively studied, and different studies suggest various determinants.

Psychological reactions of the person include the feeling of shock, fear, unable to accept reality, until a long sympathetic response such as a state of depression [1]. Sympathetic response that lasts a long time and excessive will cause chronic stimulation in cancer patients causing blood pressure to rise, arteriosclerotic changes, cardiovascular disease [2]. Behavior patterns of withdrawal and depression decrease immune response, extend the number of treatment days, and lead to death in cancer patients [3].
Effective coping mechanism produces a permanent adaptation and improves quality of life, while ineffective coping ends in behavior that deviates from the normative desires and generates self-harm [4]. The process of cancer therapy, which usually takes a long duration of time, requires an adequate of social support from the family [5]. Cancer patients who have effective coping mechanisms have better health status than patients with less effective coping mechanisms [6, 7]. Furthermore, social support and coping mechanisms have also been proven to be important factors among cancer patients undergoing the treatment [7].

Nurses are important source of social support for cancer sufferers. Nurses should have an understanding and sensitivity to the situation and challenges experienced by cancer patient, thus professional nurses can provide support and more individual care for cancer sufferers during their lifetime who are vulnerable to various complications that may occur [8].

Maladaptive cancer patients can be prevented by increasing coping mechanisms through increased social support from people around. Thus, the objective of this study is to analyze what factors are related to the 
Coping Mechanism in Cancer Patients in a Hospital in Aceh Province.

\section{METHOD}

The populations in this cross-sectional study were all cancer patients undergoing chemotherapy at General Hospital during November to December 2019.Factors related to the Coping Mechanism included in this study were age, education, marital status, religion, occupation, stage of cancer, caregivers, acceptance and social support. In the present study, Social support was measured using the Social Support Questioner (SSQ) by Sarason, et al. [9].The SSQ6 scale is a Likert scale with six response choices that are continuous. Subjects were asked to choose one of the six answer choices available, which illustrates the appropriateness of social support that the subject received from his partner. Coping mechanisms was measured using Maladaptive and Adaptive Coping Style (MAXS) by Moritz et al. [10].The Maladaptive and Adaptive Coping Style (MAXS) questionnaire has 21 statement items consisting of adaptive coping, maladaptive coping and avoidance statements. This questionnaire uses a 1- 4 Likert scale where each item has 4 possible answers the questionnaire carried out the process of translating and adapting the instrument aimed at achieving a different language version of the English language instrument which is conceptually equivalent in each country or culture. The association between independent variables and coping mechanism was tested using a chi-squared test. A linear regression analysis was performed to estimate factors that independently associated with coping mechanism among cancer patients

\section{ReSUlT}

All respondents of the study were Muslim which is 28 people between ages 46 and 55 years old $(39,4 \%)$, the education level of 30 respondents $(42.3 \%)$ secondary education, marital status of 57 respondents $(80.3 \%)$ were married, religiosity of 63 respondents $(88.7 \%)$ do it regularly, 39 respondents $(54.9 \%)$ were employed, cancer stage of 29 respondents $(40.8 \%)$ were stage II cancer, 61 respondents $(85.9 \%)$ obtained caregivers who treat, 53 respondents $(74.6 \%)$ accepted the disease, contextual stimulus in the form of social support for cancer patients of 55 respondents $(77.5 \%)$ received high social support, and coping mechanisms of patients with cancer of 48 respondents $(67.6 \%)$ were in adaptive category.

\section{Bivariate Test Result}

Correlation between independent variables and coping mechanism of cancer patient in one hospital in Aceh Province are tested with Chi-Square test. The results of data analysis are served in the table 2 as follows:

Table-2: Relationship of Factors Affecting Coping with the Coping Mechanism of Cancer Patients in One Hospital in Aceh Province $(n=71)$

\begin{tabular}{|c|c|c|c|c|c|}
\hline \multirow[t]{2}{*}{ Factors } & \multicolumn{2}{|c|}{ Coping Mechanism } & \multirow{2}{*}{$\begin{array}{l}\text { Total } \\
\mathbf{f}(\%)\end{array}$} & \multirow[t]{2}{*}{$\alpha$} & \multirow[t]{2}{*}{ P-Value } \\
\hline & $\begin{array}{l}\text { Adaptive } \\
\text { f }(\%)\end{array}$ & $\begin{array}{c}\text { Maladaptive } \\
\text { f }(\%)\end{array}$ & & & \\
\hline \multicolumn{6}{|l|}{ Education } \\
\hline Senior High School & $9(47,4 \%)$ & $10(52,6 \%)$ & $19(100 \%)$ & \multirow[t]{4}{*}{0,05} & \multirow[t]{4}{*}{0,059} \\
\hline Junior High School & $21(70,0 \%)$ & $9(30,0 \%)$ & $30(100 \%)$ & & \\
\hline Primary School & $18(81,8 \%)$ & $4(18,2 \%)$ & $22(100 \%)$ & & \\
\hline Total & $48(67,6 \%)$ & $23(32,4 \%)$ & $71(100 \%)$ & & \\
\hline \multicolumn{6}{|l|}{ Marital Status } \\
\hline Not Married & $0(0 \%)$ & $3(100 \%)$ & $3(100 \%)$ & \multirow[t]{5}{*}{0,05} & \multirow[t]{5}{*}{0,200} \\
\hline Married & $41(71,9 \%)$ & $16(28,1 \%)$ & $57(100 \%)$ & & \\
\hline Widow & $5(62,5 \%)$ & $3(37,5 \%)$ & $8(100 \%)$ & & \\
\hline Widower & $2(66,7 \%)$ & $1(33,3 \%)$ & $3(100 \%)$ & & \\
\hline Total & $48(67,6 \%)$ & $23(32,4 \%)$ & $71(100 \%)$ & & \\
\hline \multicolumn{6}{|l|}{ Religious } \\
\hline Yes & $44(42,6 \%)$ & $19(26,8 \%)$ & $63(100 \%)$ & \multirow[t]{3}{*}{0,05} & \multirow[t]{3}{*}{0,423} \\
\hline Ordinary & $4(5,6 \%)$ & $4(5,6 \%)$ & $8(100 \%)$ & & \\
\hline Total & $48(67,6 \%)$ & $23(32,4 \%)$ & $71(100 \%)$ & & \\
\hline \multicolumn{6}{|l|}{ Occupation } \\
\hline Employed & $23(59,0 \%)$ & $16(41,0 \%)$ & $39(100 \%)$ & \multirow[t]{3}{*}{0,05} & \multirow[t]{3}{*}{0,144} \\
\hline Unemployed & $25(78,1 \%)$ & $7(21,9 \%)$ & $32(100 \%)$ & & \\
\hline Total & $48(67,6 \%)$ & $23(32,4 \%)$ & $71(100 \%)$ & & \\
\hline
\end{tabular}




\begin{tabular}{|c|c|c|c|c|c|}
\hline \multicolumn{6}{|l|}{ Cancer Stage } \\
\hline I & $9(52,9 \%)$ & $8(47,1 \%)$ & $17(100 \%)$ & \multirow[t]{5}{*}{0,05} & \multirow[t]{5}{*}{0,187} \\
\hline II & $21(72,4 \%)$ & $8(27,6 \%)$ & $29(100 \%)$ & & \\
\hline III & $14(82,4 \%)$ & $3(17,6 \%)$ & $17(100 \%)$ & & \\
\hline IV & $4(50,0 \%)$ & $4(50,0 \%)$ & $8(100 \%)$ & & \\
\hline Total & $48(67,6 \%)$ & $23(32,4 \%)$ & $71(100 \%)$ & & \\
\hline \multicolumn{6}{|c|}{ Present of caregiver } \\
\hline Yes & $46(75,4 \%)$ & $15(24,6 \%)$ & $61(100 \%)$ & \multirow[t]{3}{*}{0,05} & \multirow[t]{3}{*}{0,001} \\
\hline No & $2(20,0 \%)$ & $8(80,0 \%)$ & $10(100 \%)$ & & \\
\hline Total & $48(67,6 \%)$ & $23(32,4 \%)$ & $71(100 \%)$ & & \\
\hline \multicolumn{6}{|l|}{ Acceptance } \\
\hline Yes & $44(83,0 \%)$ & $9(17,0 \%)$ & $53(100 \%)$ & \multirow[t]{3}{*}{0,05} & \multirow[t]{3}{*}{0,000} \\
\hline No & $4(22,2 \%)$ & $14(77,8 \%)$ & $18(100 \%)$ & & \\
\hline Total & $48(67,6 \%)$ & $23(32,4 \%)$ & $71(100 \%)$ & & \\
\hline \multicolumn{6}{|c|}{ Social Support } \\
\hline High & $46(83,6 \%)$ & $9(16,4 \%)$ & $55(100 \%)$ & \multirow[t]{3}{*}{0,05} & \multirow[t]{3}{*}{0,000} \\
\hline Low & $2(12,5 \%)$ & $14(87,5 \%)$ & $16(100 \%)$ & & \\
\hline Total & $48(67,6 \%)$ & $23(32,4 \%)$ & $71(100 \%)$ & & \\
\hline
\end{tabular}

Based on Table. 2 can be identified that there is significant relation between age factors with coping mechanism on $\alpha=0,05$ and $P$-value 0,668 , education get $P$-value 0,059 ,marital status get $P$-value 0,200, religious get $P$-value 0,423 , occupation get $P$-value 0,144 , cancer stage get $P$-value 0,187 , present of care giver get $P$-value 0,001 , and acceptance get $P$-value $0,000<0,05$.

\section{Multivariate Test Result}

Table-3: Result of First Step Multivariate Logistic Regression Analysis Results with the Stepwise Method for the Implementation of Coping Mechanism in One Hospital in Aceh Province $(n=71)$

\begin{tabular}{|c|c|c|c|c|c|}
\hline \multirow[t]{2}{*}{ Variable } & \multirow[t]{2}{*}{ B } & \multirow[t]{2}{*}{ Sig. } & \multirow[t]{2}{*}{$\operatorname{Exp}(B)$} & \multicolumn{2}{|c|}{ 95\% C.I.for EXP(B) } \\
\hline & & & & Lower & Upper \\
\hline Age & .167 & .848 & 1.182 & .212 & 6.579 \\
\hline Education & -.538 & .484 & .584 & .130 & 2.634 \\
\hline Marital Status & -.548 & .638 & .578 & .059 & 5.694 \\
\hline Occupation & 2.254 & .140 & 9.530 & .478 & 190.030 \\
\hline Cancer Stadium & .181 & .712 & 1.199 & .458 & 3.135 \\
\hline Caregiver & -2.649 & .193 & .071 & .001 & 3.812 \\
\hline Acceptance & -3.181 & .003 & .042 & .005 & .340 \\
\hline Social Support & -4.611 & .002 & .010 & .001 & .182 \\
\hline
\end{tabular}

Model 1 result shows that from eight related factors with coping mechanism, there are two factors have $P$-value $<0,05$, it means every factor have significant correlation with coping mechanism. On acceptance factor has $P$-value $0,003<0,05$ and social support has $P$-value $0,002<0,05$. Therefor only acceptance and social support which can be examined in next model.

Table-4: Result of Second Step Multivariate Logistic Regression Analysis Results with the Stepwise Method for the Implementation of Coping Mechanism in One Hospital in Aceh Province (n=71)

\begin{tabular}{|c|c|c|c|c|c|}
\hline \multirow[t]{2}{*}{ Variable } & \multirow[t]{2}{*}{ B } & \multirow[t]{2}{*}{ Sig. } & \multirow[t]{2}{*}{$\operatorname{Exp}(B)$} & \multicolumn{2}{|c|}{ 95\% C.I.for EXP(B) } \\
\hline & & & & Lower & Upper \\
\hline Acceptance & -3.128 & .000 & .044 & .008 & .235 \\
\hline Social Support & -3.849 & .000 & .021 & .003 & .145 \\
\hline
\end{tabular}

Model result shows the two factors are significantly related to coping mechanism, meanwhile the most significant related factor to coping mechanism is acceptance factor which is proven by $P$-value $0,000<$ 0,05 and has biggest OR value 0,044 .

\section{DISCUSSION}

The age factor has no relationship with the coping mechanism (p-value 0,668). Nawa, et al. [11] stated that there was no relationship between age and coping mechanisms on the survival of cancer patients. The research by Wardhani [12] stated that the high-risk age group had a greater number of patients, which were 
$119(96.0 \%)$, compared to the number of low risk age group, which were $5(4.0 \%)$ patients. The average age of patients in this study was $49.50 \pm$ SD years with the youngest age is 19 years old and the oldest age is 75 years old. Individual coping mechanisms can be formed from the experience. Individuals with a lot of experience on the matter will certainly make a strong response both psychologically and physically. The experience helped them in adapting and coping mechanisms because many were exposed to the activities or events that had been carried out in the past.

The marital status variable obtained by the chi square test results with a significant value of 0,200 and shows no relationship. Research by Wardhani [13] stated that there are 122 married patients $(98.4 \%)$ and patients who were not married as many as $2(1.6 \%)$ patients. More of married patients were taken as the sample $(98.4 \%)$. There are $68.0 \%$ of married carcinoma cervices uteri patients. These results are consistent with the literature which says that the incidence is higher in women who are married. An unmarried individual has a stronger coping mechanism because he only thinks of himself without the dependents of others who depend on him. Marital status is closely related to thinking of people who depend on him such as husband, wife and children who are important in his life to create a weak coping mechanism.

A meta-analysis study conducted by Dumrongpanapakorn [8] stated that the loss of body parts, such as breasts, is seen as part of the suffering in life given by God. As a human being, one must deal with illness and death. However, losing an organ is better than losing a person's life. This helped the women in the study to be more receptive to losing their body parts and thought that organ loss was a gift from God.

In the results of research with work variables, the results of the chi square test with a significant value of 0.144 and shows no relationship. Research conducted by Schernhammer, et al. [14] showed the relationship between the type of work and the risk of breast cancer. More demanding work is associated with a moderate reduction in breast cancer risk: Women with active work have a 17 percent lower risk of developing breast cancer than women with low heavy work. Work can strengthen the adaptive coping mechanism in an individual, structured activities every day and coworkers as a place to share information and provide positive support. Individuals who do not have a job are often found to have a closed nature and do not want to share information with others.

The results of this study in terms of the stage of cancer were contrary to research conducted by Astanti, et al. [15] stated that there is a relationship between the stages of breast cancer undergoing chemotherapy.
Results from caregivers, chi square test results obtained with a significant value of 0,001 shows a relationship. The research conducted by Werdani [16] showed that there is an effect of care giving on the level of caregiver burden with the magnitude of influence is $69.9 \%$. The results of this study are in line with this study that there is a relationship between caregivers and coping mechanisms.

This study shows a relationship between acceptance and social support with coping mechanisms, this is in accordance with the results of research Kamińska, et al. [17] stated that good acceptance of breast cancer was obtained by women treated for breast cancer who had undergone mastectomy (64\%) in undergoing adjuvant endocrine therapy. Afiyah [1] stated that if social support is good, patients will easily adapt to their illness. Conversely, if social support is lacking, then patients will find it difficult to adapt to the disease.

\section{CONCLUSION}

The conclusions of this study are age, caregiver, acceptance and social support related to coping mechanisms in cancer patients at a hospital in Aceh Province. Variables significantly related to coping mechanisms are social acceptance and support.

\section{REFFERENCES}

1. Afiyah, R. K. (2018). Dukungan Keluarga Mempengaruhi Kemampuan Adaptasi (Penerapan Model Adaptasi Roy) Pada Pasien Kanker Di Yayasan Kanker Indonesia Cabang Jawa Timur. Journal of Health Sciences, 10(1), 96-105.

2. Azwar, B. (2012). Buku Panduan Pasien Kemoterapi. Jakarta: Dian Rakyat

3. Brunner. \& Suddarth. (2012). Buku Ajar Keperawatan Medikal Bedah Edisi 8 volume 2. Jakarta EGC.

4. Maulina, R., \& Bahri, T. S. (2016). The Coping Mechanism of Cancer Patients Undergoing Chemotherapy In Dr . Zainoel Abidin General Hospital of Banda Aceh. Jurnal Endurance, 2(3), $1-6$.

5. Koffman, J., Higginson, I. J., Hall, S., Riley, J., McCrone, P., \& Gomes, B. (2012). Bereaved relatives' views about participating in cancer research. Palliative Medicine, 26(4), 379-383.

6. Lazarus, R. S., \& Monat, A. (1984). Personalidade (V. Ribeiro, Trad.).

7. Yang, Y., Sun, G., Dong, X., Zhang, H., Xing, C., \& Liu, Y. (2019). Preoperative Anxiety In Chinese Colorectal Cancer Patients: The Role Of Social Support, Self-Esteem And Coping Styles. Journal of Psychosomatic Research, (February), 1-7.

8. Dumrongpanapakorn, P., \& Liamputtong, P. (2017). Social Support and Coping Means: The Lived Experiences of Northeastern Thai Women with 
Breast Cancer. Health Promotion International, 32(5), 768-777.

9. Sarason, I. G., Levine, H. M., Basham, R. B., \& Sarason, B. R. (1983). Assessing social support: the social support questionnaire. Journal of personality and social psychology, 44(1), 127.

10. Moritz, S., Lüdtke, T., Westermann, S., Hermeneit, J., Watroba, J., \& Lincoln, T. M. (2016). Dysfunctional coping with stress in psychosis. An investigation with the Maladaptive and Adaptive Coping Styles (MAX) questionnaire. Schizophrenia research, 175(1-3), 129-135.

11. Nawa, N., Isumi, A., \& Fujiwara, T. (2018). Community-level social capital, parental psychological distress, and child physical abuse: a multilevel mediation analysis. Social psychiatry and psychiatric epidemiology, 53(11), 1221-1229.

12. Dimatteo, M. R. (2011). Social Support And Patient Adherence To Medical Treatment: A MetaAnalysis. Health Psychology Journal, 23, 2, 207218
13. Wardhani, S. (2011). Instrumen penilaian hasil belajar matematika SMP: Belajar dari PISA dan TIMSS. Yogyakarta: P4TK Matematika.

14. Schernhammer, E. S., \& Colditz, G. A. (2004). Suicide rates among physicians: a quantitative and gender assessment (meta-analysis). American Journal of Psychiatry, 161(12), 2295-2302.

15. Astanti, K. Y., \& Yustini, M. D. (2017, February). Hubungan pengetahuan dan sikap ibu post partum primipara tentang cara menyusui dengan praktik ibu menyusui di ruang baitunnisa rumah sakit islam sultan agung semarang. In prosiding seminar nasional \& internasional.

16. Wardani, D. N., Toenlioe, A. J., \& Wedi, A. (2018). Daya tarik pembelajaran di era 21 dengan Blended Learning. Jurnal Kajian Teknologi Pendidikan, 1(1), 13-18.

17. Sivanesan, A., Witkowska, E., Adamkiewicz, W., Dziewit, Ł., Kamińska, A., \& Waluk, J. (2014). Nanostructured silver-gold bimetallic SERS substrates for selective identification of bacteria in human blood. Analyst, 139(5), 1037-1043. 